\title{
Effect of Chemical Defoliation, Irrigation Water, and Distance From the Pivot on Late Blight Tuber Rot in Center-Pivot Irrigated Potatoes in the Columbia Basin
}

\author{
Dennis A. Johnson, Department of Plant Pathology, Washington State University, Pullman 99164-6430, Mel Martin, \\ Food Group, J.R. Simplot Co., and Thomas F. Cummings, Department of Plant Pathology, Washington State University
}

\begin{abstract}
Johnson, D. A., Martin, M., and Cummings, T. F. 2003. Effect of chemical defoliation, irrigation water, and distance from the pivot on late blight tuber rot in center-pivot irrigated potatoes in the Columbia Basin. Plant Dis. 87:977-982.

Chemical desiccation of potato foliage 2 to 3 weeks prior to harvesting tubers is commonly recommended to reduce late blight tuber rot. Observations in commercial fields indicate that this practice may not be needed to manage tuber rot in the semiarid environment of the Columbia Basin. Potatoes in this region are mostly grown under center pivot irrigation, and a relatively high volume of irrigation water is often delivered near the pivot in center-pivot irrigated fields. This study evaluated the effect of chemical desiccation of potato foliage on late blight tuber rot and quantified the incidence of late blight tuber rot in relation to distance from the pivot and the amount of irrigation water applied in center-pivot irrigated fields. Potato foliage was chemically desiccated or not desiccated within 41 to $76 \mathrm{~m}$ of the pivot of center-pivot irrigated potato fields 2 to 3 weeks before harvest in replicated plots in five field trials during 3 years. Incidence of late blight tuber rot did not differ significantly between the defoliated and nondefoliated plots in all five trials. Incidence of tuber rot significantly increased as amount of irrigation water applied increased, and was significantly greater within $30 \mathrm{~m}$ of the center pivot than at greater distances in two trials in 1998 and two trials in 1999. Tuber rot did not develop in a fifth trial in 2000 where a water gradient did not occur among the plots. The largest percentage of tubers infected with late blight was observed within 30 days of harvest at a storage temperature of $9^{\circ} \mathrm{C}$. Chemical desiccation of potato foliage in the semiarid environment of the Columbia Basin was not beneficial in reducing late blight tuber rot, but growing potatoes within $30 \mathrm{~m}$ of the pivot will likely increase the number of infected tubers going into storage.
\end{abstract}

The Columbia Basin of south-central Washington and north-central Oregon is a major potato growing area in North America. Over 65,000 ha of potatoes are grown in the area annually, with mean tuber yields in excess of $74 \mathrm{t} / \mathrm{ha}$ (30 t/acre) (27). Mean total rainfall in this semiarid region during the main cropping season (April to September) over a 12-year period (1989 to 2000) in the Basin ranged from $81 \mathrm{~mm}$ at Moses Lake, WA, in the north to $79 \mathrm{~mm}$ at Paterson, WA, in the south (21). The potato crop is irrigated mostly by center-pivot systems. Nearly $87 \%$ of the potato crop is processed, and a high percentage of these tubers are stored for up to 10 months.

Late blight, caused by Phytophthora infestans (Mont.) de Bary, was first reported in central Washington on potato in 1947. It was 27 years before the next occurrence in 1974, and disease outbreaks occurred seven times over the next 16 years (8). Late blight now is an annual concern in the Columbia Basin. The US-8 clonal lineage

Corresponding author: Dennis A. Johnson

E-mail: dajohn@wsu.edu

Accepted for publication 2 April 2003.

Publication no. D-2003-0602-02R

(C) 2003 The American Phytopathological Society has predominated in the area since 1995 (15) and is highly aggressive on potato foliage and tubers $(16,17)$. The cost of late blight management in the Columbia Basin was \$22.3 million in 1998. This cost included $\$ 19.8$ million for fungicides and application, $\$ 1.1$ million for canopy desiccation, and $\$ 1.4$ million in losses due to tuber rot in storage (9). Tuber rot due to late blight is a major concern for the potato industry in the Columbia Basin. A majority of the potato crop is stored for extended time periods, and tuber rot can result in substantial losses $(9,10)$. P. infestans usually does not spread in storage, but secondary infection by Pectobacterium spp. (Erwinia) can rapidly spread and destroy potatoes in storage (25).

Management of potato late blight in the Columbia Basin requires an integrated approach that includes using disease-free seed tubers, destroying refuse tubers and volunteer potatoes, treating seed tubers with a fungicide product containing mancozeb or cymoxanil $(4,20)$, managing irrigation water, adequately hilling soil over developing tubers, applying fungicides to foliage in a timely manner, and harvesting during dry weather (25). Late blight forecasting models coupled with weather forecasts are utilized to schedule fungicide applications for the region $(7,8)$.
Managing irrigation water is crucial in reducing late blight in an irrigated, semiarid environment (23). Late blight is often more severe in fields with excessive irrigation (more water applied than lost through evapotranspiration), where two irrigation systems overlap, and near the center of the irrigation pivot because many center-pivot systems typically deliver up to $50 \%$ more water in areas of the field less than $30 \mathrm{~m}$ from the pivot center than at greater distances (Terry Miller, Miller Research, Rupert, ID, personal communication). The relationship between incidence of late blight tuber rot and proximity to the pivot has not been established.

Chemical desiccation of potato foliage, or "vine killing," before harvest is an important component of managing late blight tuber rot in many areas of the world $(1,25)$, and this practice is recommended for management of late blight tuber rot in the $\mathrm{Pa}$ cific Northwest. Complete death of foliage is necessary for approximately 1 to 2 weeks before harvest in order to reduce inoculum present on living foliar tissue (25). Since it takes at least 1 week in the Columbia Basin for potato foliage to die after application of a desiccant, chemical desiccants must be applied 2 to 3 weeks before intended harvest. Vine killing may also aid tuber periderm maturation and help reduce diseases caused by wound invading pathogens. In a recent study, skinning of tuber periderm at harvest did not increase tuber infection by $P$. infestans (12). The disadvantages of vine killing are $\$ 86.50$ per ha ( $\$ 35$ per acre) expense for chemicals and application $(9,10)$, and a potential reduction in tuber yield because the growing season is reduced up to 3 weeks (25). Recent research indicates that vine killing may not reduce tuber rot due to late blight in the semiarid environment of the Columbia Basin (9).

A major processor in the Columbia Basin has discouraged chemical desiccation of vines before harvest for over three decades, mainly because specific gravity of tubers is thought to be higher if tubers are harvested when the vines are still green. High specific gravity is desired when processing tubers for French fries. Ranger Russet tubers from vine-killed foliage also have a tendency to build up reducing sugars, and thus lose processing quality faster during storage than tubers harvested from green foliage (11). Tuber rot from fields not desiccated before harvest has not 

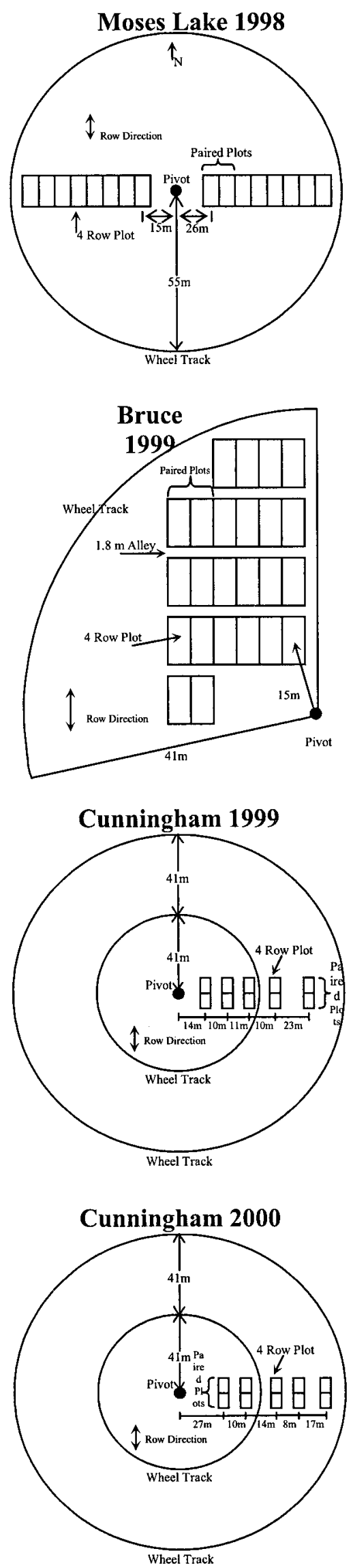

Fig. 1. Orientation of plots in commercial potato fields near Moses Lake in 1998, Bruce in 1999, Cunningham in 1999, and Cunningham in 2000 in south-central Washington. appeared to be more prevalent than that from desiccated fields (unpublished data), but quantitative data from controlled experiments in irrigated fields are needed to demonstrate the effectiveness of desiccating potato foliage to manage late blight tuber rot in the Columbia Basin. The objectives of this research were to evaluate the effectiveness of desiccating potato foliage for the management of late blight tuber rot and to quantify relative incidence of blight tubers associated with distance from the pivot and with the amount of irrigation water applied in irrigated potato fields in the Columbia Basin.

\section{MATERIALS AND METHODS}

Commercial potato fields in the Columbia Basin of central Washington were scouted during the 1998-2000 growing seasons for late blight, and fields were selected in August of the years included in the study. Fields were selected on the basis of having foliage infected with late blight and with the understanding that protectant fungicides would be applied weekly until harvest.

Potato foliage with symptoms of late blight in commercial fields was either chemically defoliated or not defoliated in replicated plots 3 weeks before harvest in two trials in one field in 1998, 2 weeks before harvest in two trials in separate fields in 1999, and 2 weeks before harvest in one trial in one field in 2000. Cultivar Russet Burbank was planted in 1998 and cultivar Ranger Russet was planted in 1999 and 2000. Foliage and tubers of both cultivars are susceptible to $P$. infestans $(3,14)$. All fields were located in central Washington and were planted with certified seed tubers in silt loam soil. Fields were located near Moses Lake in 1998, near Bruce and near Cunningham in 1999, and near Cunningham in 2000 (different fields were used at Cunningham during the 2 years). Fields were full circles, except at Bruce in 1999, which was a quarter-circle. Plots were four rows wide and $6.1 \mathrm{~m}$ long, with a between-row spacing of $0.86 \mathrm{~m}$.

Plots were defoliated with diquat dibromide (Diquat, Syngenta Crop Protection) at 1.75 liters/ha (1.5 pts/acre) in 655 liters of water per hectare (70 gal water per acre) using a lever-pumped, backpack sprayer on 11 September at Moses Lake in 1998, on 25 August at Bruce and on 10 and 13 September at Cunningham in 1999, and on 1 September at Cunningham in 2000. The sprayer had a hand-held boom with a single broad jet nozzle, which allowed the spray material to be directed only at foliage in plots. The herbicide, diquat dibromide, was applied 144 to 154 days after planting at the four locations. Foliage, except that with late blight lesions, was green at all locations when Diquat was applied. Two applications at a 3-day interval were needed at Cunningham in 1999 to obtain thorough desiccation of foliage.
Paired plots (chemically defoliated and nondefoliated) were placed between the center pivot and the first tower at Moses Lake in 1998 and at Bruce in 1999, and between the center pivot and the second tower at Cunningham in 1999 and 2000 (Fig. 1). Plot rows were oriented perpendicular (90 degrees) to the pivot line at Moses Lake in 1998 and Cunningham in 1999 and 2000 (Fig. 1). At Moses Lake, the randomized pairs were side by side, and each successive plot increased in distance from the pivot. The distance between the centers of plots was $3.4 \mathrm{~m}$. The two treatments were replicated four times each on the east and west sides of the pivot (Fig. 1). At Cunningham in 1999 and 2000, paired plots of the two treatments were placed end to end (lengthwise) so that both treatments of a replication were the same distance from the pivot center (Fig. 1). Five replicates were used. Distance between replicates varied from 10 to $23 \mathrm{~m}$ to avoid the pivot wheel line, and so that a pair of plots was located more than $60 \mathrm{~m}$ from the pivot center (Fig. 1). At Bruce in 1999, 12 pairs of defoliated and nondefoliated plots were used. Because the field was a quarter-circle, the plots were placed away from the edges of the field where the pivot line (boom) reversed travel and caused an excessively wet edge effect. Consequently, paired plots were randomly place through about a 70-degree sweep of the pivot line at distances to the center of plots ranging 16 to $37 \mathrm{~m}$ from the pivot (Fig. 1).

Distance from center pivot to the center of the first plot was $26 \mathrm{~m}$ east of the pivot and $15 \mathrm{~m}$ west of the pivot at Moses Lake in $1998,15 \mathrm{~m}$ at Bruce and $14 \mathrm{~m}$ at Cunningham in 1999, and $27 \mathrm{~m}$ at Cunningham in 2000. Distance to the plot farthest from the center pivot was $52 \mathrm{~m}$ east of the pivot and $41 \mathrm{~m}$ west of the pivot at Moses Lake in 1998, $37 \mathrm{~m}$ at Bruce and $68 \mathrm{~m}$ at Cunningham in 1999, and $76 \mathrm{~m}$ at Cunningham in 2000. Irrigation water was measured with rain gauges placed approximately $1 \mathrm{~m}$ above the soil level in each replicate for a 7- to 10-day period just before and after desiccation in 1999 and 2000, and for one revolution (cycle) of the pivot line after harvest in 1998.

Fungicides were applied at labeled rates for late blight management in each field on a 7-day interval from at least 3 weeks before vine kill until 7 days before harvest. Mancozeb (Dithane M-45, Dow Agro Sciences, formerly Rohm and Haas) and chlorothalonil (Bravo WS, Syngenta Crop Protection, formerly ISK Bioscience) were used in 1998 and 1999, and dimethomorph (Acrobat 50WP, BASF Corp., formerly American Cyanamid Co.) plus mancozeb (Dithane M-45) and cymoxanil (Curzate 60DF, DuPont Agri Products) plus mancozeb (Dithane M-45) were used in 2000. These fungicides and fungicide mixtures do not differ significantly in control of potato late blight in the field (unpublished data). 
Plants in fields were infected by naturally occurring inoculum. Late blight was observed about 3 weeks before vine kill in each field where plots were established. Severity of late blight on foliage in plots was similar to that on plants throughout the section of the field where plots were established. The late blight pathogen was isolated from foliage on rye extract agar (22), and the clonal lineage of one randomly selected isolate from each field was determined (2). Incidence and severity of late blight were determined at harvest in the two center rows of nondesiccated plots at Moses Lake in 1998 and Bruce in 1999, and in a $10-\mathrm{m}$ section of row of nondesiccated foliage in a second row from each plot at Cunningham in 1999 and 2000. Plant rows adjacent to plots were not desiccated, and rows used for disease assessment were bordered by nondesiccated rows. Numbers of plants with and without disease symptoms were counted to calculate disease incidence, and the percentage of surface area of foliage with symptoms was estimated for disease severity according to a late blight assessment key (5).

The center two rows of each plot were harvested on 1 October at Moses Lake in 1998, on 7 September at Bruce and on 28 September at Cunningham in 1999, and on 15 September at Cunningham in 2000. Tubers were hand harvested in 1998, but mechanically dug with a single-row harvester in 1999 and 2000. Weather was sunny and dry during harvest each year. Tubers from one harvested row were weighed for yield and used to determine specific gravity, which was calculated with the formula: specific gravity $=$ weight of tubers/(weight of tubers minus weight of tubers submerged in water). Tubers from the other harvested row were placed in two burlap bags and used for disease assessment. Mean tuber numbers per plot used to assess blighted tubers were 189 on the east and 168 on the west side of the pivot at Moses Lake in 1998, 188 at Bruce and 156 at Cunningham in 1999, and 231 at Cunningham in 2000.

Tubers each year were stored in burlap bags at $9^{\circ} \mathrm{C}$ for 20 weeks. They were visually evaluated for late blight five times over a 20 -week period. The first evaluation was at or within 8 days of harvest, the second, third, fourth, and fifth assessments were 20 to 22 days, 19 to 21 days, 29 to 43 days, and 48 to 50 days, respectively, after the previous assessment. To facilitate accurate diagnosis, disease assessments were made before secondary bacteria invaded infected tissue. All tubers from each plot were individually examined during the disease assessments. Tubers with external symptoms of disease were sliced with a knife to observe internal symptoms. Representative tubers with disease were placed in moist chambers to induce sporulation of $P$. infestans. The number of tubers with symptoms of late blight was recorded, and infected tubers were removed from storage after each assessment. Total number of tubers with symptoms of late blight from all assessments per plot was used for data analyses.

Data at each location were analyzed separately. Regression analyses of amount of irrigation water (dependent variable) by distance from the pivot (independent variable), percentage of tuber rot (dependent variable) by distance from the pivot (independent variable), percentage of tuber rot (dependent variable) by amount of irrigation water (independent variable), incidence and severity of late blight on foliage (dependent variables) by distance from the pivot (independent variable), incidence and severity of late blight on foliage (dependent variables) by amount of water applied (independent variable), and incidence of tuber rot (dependent variable) by incidence and severity of late blight on foliage (independent variables) were conducted using the REG procedure of SAS (SAS Release 8.0, SAS Institute, Cary, NC). Data were analyzed using the best least square fit using the linear $(y=a+b x)$, logarithmic $(y=b \log x)$, and power curve $\left(y=c x^{b}\right)$ regression models $(13,24)$. In the linear model, $a$ is the $y$ intercept and $b$ is the rate of increase (or negative increase) of $y$ relative to $x$. In the logarithmic model, $b$ is the rate of increase of $y$ to $\log x$. In the power model, $b$ is the rate of increase of $\log y$ to $\log x$ while $\log c$ is the intercept. The level of significance and coefficient of determination were derived from the intrinsic linear transformation of the logarithmic model $(y=\log x)$ and the power model $(\log y=\log c+b \log x)$. Percentage of blight tubers was also analyzed as a twoway analysis of variance using one replicate per treatment combination with one factor qualitative (defoliated or not defoliated) and the other factor quantitative (distance from the pivot) (12) by the GLM procedure of SAS (SAS Release 8.0). A second analysis of variance was done as before but with amount of irrigation water as the quantitative factor. An interaction between desiccation treatment and either distance from the pivot or amount of irrigation water was not found in either analysis, so the $F$ test for desiccation treatment was used to determine if there was a significant overall treatment effect. Confidence intervals at $95 \%$ were calculated for the mean percentage of late blight infected tubers that were observed from the day of harvest up to 30 days after harvest (24). Data for yield and specific gravity were analyzed using Student's $t$ tests.

\section{RESULTS}

Late blight incidence on the foliage was 60 to $90 \%$ with a 5 to $10 \%$ severity on the east side of the pivot, and it was 40 to $50 \%$ with a $5 \%$ severity on the west side of the pivot at Moses Lake in 1998. Incidence of late blight on foliage was 15 to $20 \%$ with a
10 to $30 \%$ severity at Bruce in 1999 , and incidence was 5 to $10 \%$ with a 5 to $10 \%$ severity at Cunningham in 1999. Late blight incidence on foliage was 10 to $20 \%$ with a 10 to $20 \%$ severity at Cunningham in 2000. Final incidence and final severity of late blight on foliage were not related to distance from the pivot or to amount of water applied (nonsignificant slope, $P>$ $0.10)$ in the area sampled at any location. Isolates of $P$. infestans from each field trial in the 3 years were of the US- 8 clonal lineage.

Foliage was completely dead within 9 days after diquat dibromide application at each location. Foliage in nondefoliated plots was green at harvest, except for foliage infected with late blight.

Incidence of late blight tuber rot was not related to final incidence or final severity of late blight on foliage at any of the locations $(P>0.05)$, and was not different $(P>$ 0.05 ) between defoliated and nondefoliated plots in all five field trials (Table 1). Interactions between distance from the pivot and foliar desiccation and between amount of irrigation water and foliar desiccation on the incidence of late blight tuber rot were not significant at any location $(P>0.05)$.

Amount of irrigation water significantly decreased from the center of the pivot to approximately $30 \mathrm{~m}$ from the center pivot at Moses Lake in 1998, Bruce in 1999, and Cunningham in 1999 (Fig. 2). Data were described by curved lines using the general formula $y=c x^{b}$. Coefficients of determination were $0.72(P<0.001)$ at Moses Lake, $0.98(P<0.0001)$ at Bruce, and $0.74(P<$ 0.02) at Cunningham in 1999. Amount of irrigation water was uniform over distance among the plots at Cunningham in 2000 (nonsignificant slope, $P>0.10$, Fig. 2).

Percentage of late blight tuber rot significantly increased as distance to the center pivot decreased on the east and west sides of the pivot at Moses Lake in 1998 and at Bruce and Cunningham in 1999. Data were described by a logarithmic regression $(P<0.05)$ on the east side of the pivot at Moses Lake in 1998 (Fig. 3). Data were described by curved lines using the general formula $y=c x^{b}$ on the west side of the pivot at Moses Lake in $1998(P<0.01)$ and at Bruce $(P<0.01)$ and Cunningham $(P<0.0002)$ in 1999 (Figs. 4 to 6). Totals of $90,89,91$, and $92 \%$ of the infected tubers were within $30 \mathrm{~m}$ of the pivot on the east and west sides of the pivot at Moses Lake in 1998, at Bruce in 1999, and at Cunningham in 1999, respectively. Tuber rot caused by $P$. infestans did not develop in tubers harvested at Cunningham in 2000.

Percentage of late blight tuber rot increased as amount of irrigation water increased in all three fields in 1998 and 1999. Data were described by a linear regression model on the east and west sides of the pivot at Moses Lake in 1998, at Bruce in 1999, and at Cunningham in 1999 
Table 1. Mean incidence of tuber rot, yield, and specific gravity of tubers from plots where late blight infected potato was either chemically defoliated or not defoliated 2 to 3 weeks before harvest

\begin{tabular}{llc}
\hline & Defoliated & Nondefoliated \\
\hline Late blight tuber rot (\%) & & 1.0 \\
Moses Lake East 1998 & 0.2 & 5.1 \\
Moses Lake West 1998 a & 1.1 & 2.8 \\
Bruce 1999b & 4.9 & 5.9 \\
Cunningham 1999c & 1.9 & 0 \\
Cunningham 2000 & 0 & \\
Total yield (ton/ha) & & 79.0 \\
Moses Lake East 1998 & 76.6 & 73.5 \\
Moses Lake West 1998 & 74.7 & 76.6 \\
Bruce 1999 & 74.6 & 79.1 \\
Cunningham 1999 & 78.1 & 102.6 \\
Cunningham 2000*d & 94.4 & 1.0784 \\
Specific gravity & & 1.0788 \\
Moses Lake East 1998 & 1.0763 & 1.0782 \\
Moses Lake West 1998 & 1.0770 & 1.0793 \\
Bruce 1999* & 1.0744 & 1.0835 \\
Cunningham 1999* & 1.0759 & \\
Cunningham 2000 & 1.0820 & \\
\hline
\end{tabular}

a Mean of eight replicates.

b Mean of 12 replicates.

c Mean of five replicates.

${ }^{\mathrm{d}}$ Means between defoliated and nondefoliated treatments are significantly different according to $t$ test $(P<0.05)$

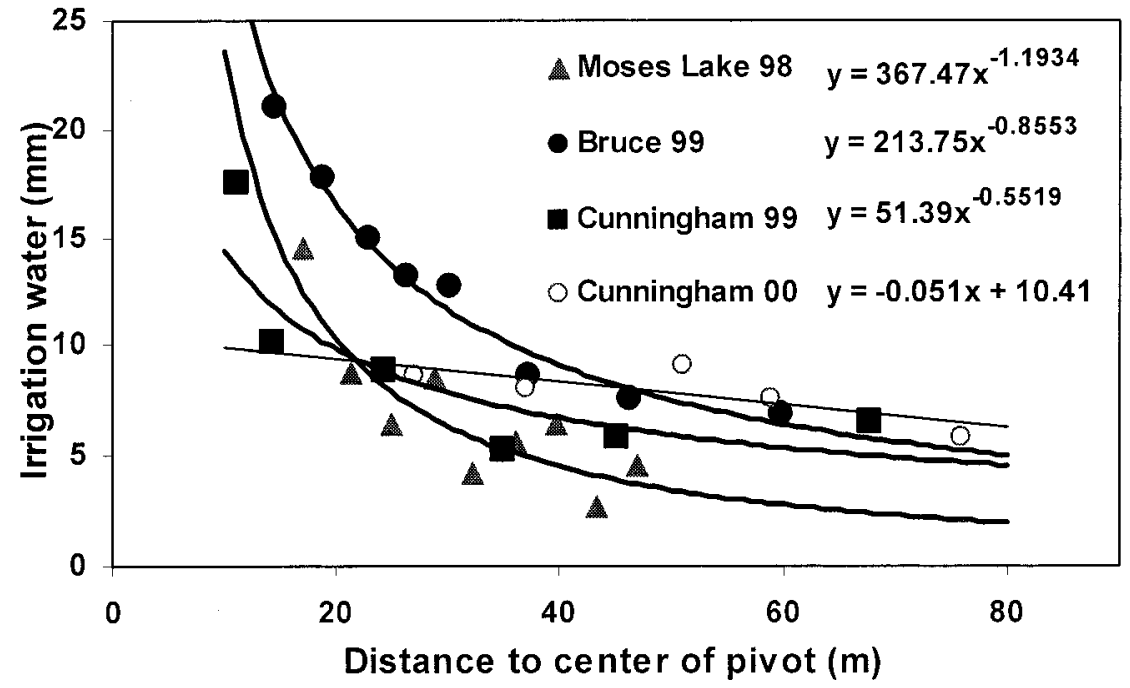

Fig. 2. Amount of irrigation water delivered in relation to distance from the center of an irrigation pivot 7 to 10 days prior to harvest in four fields in the Columbia Basin.

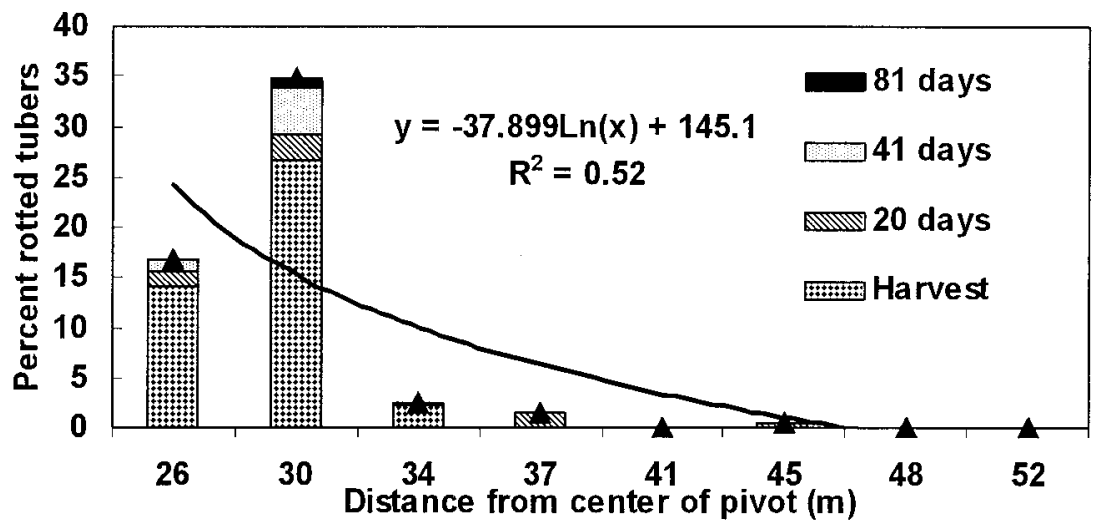

Fig. 3. Incidence of tubers of cultivar Russet Burbank infected with Phytophthora infestans in relation to distance from the center of an irrigation pivot system on the east side of a field near Moses Lake, WA, in 1998. Tubers were stored at $9^{\circ} \mathrm{C}$ and then assessed for rot over 20 weeks.
(Fig. 7). Coefficients of determination were $0.61(P<0.05)$ on the east side of the pivot at Moses Lake, $0.72(P<0.05)$ on the west side of the pivot at Moses Lake, $0.85(P<0.01)$ at Bruce, and $0.70(P<$ 0.01) at Cunningham in 1999.

Late blight tuber rot was first observed either at harvest or within 8 days of harvest. The largest percentage of blighted tubers was observed within 30 days after harvest at each location (Figs. 3 to 6). The mean percentage \pm the $95 \%$ confidence interval of infected tubers that were observed from harvest to 30 days after harvest was $89 \pm$ $7.6 \%$ on the east side of the pivot at Moses Lake, $76 \pm 8.8 \%$ on the west side of the pivot at Moses Lake, $86 \pm 4.7 \%$ at Bruce, and $66 \pm 12.1 \%$ at Cunningham in 1999 . Diseased tubers were not observed during the last disease assessment (more than 93 days after harvest) at all field trials.

Yield of the nondefoliated plots was greater $(P<0.05)$ than that of the defoliated plots at Cunningham in 2000, but yields between the two treatments were not different $(P>0.05)$ at Moses Lake in 1998 and Bruce and Cunningham in 1999 (Table 1). Specific gravity was greater $(P<0.05)$ for tubers from the nondefoliated than the defoliated plots at two of the five field trials (Table 1).

\section{DISCUSSION}

Incidence of tuber rot caused by $P$. infestans in five field trials under centerpivot irrigation in the Columbia Basin was not significantly reduced by chemical desiccation of potato foliage 2 to 3 weeks before harvest in this study. Vine killing generally is believed to be beneficial in reducing tuber rot caused by $P$. infestans in regions receiving more rainfall than the Columbia Basin (1). In semiarid environments that receive little or no rainfall during harvest, such as the Columbia Basin, foliar desiccation is less likely to reduce the incidence of tuber rot caused by $P$. infestans. Benefits of not desiccating foliage before harvest in the Columbia Basin are the savings for the cost of the desiccant and application $(\$ 86.50 / \mathrm{ha})(9,10)$, increased yields (26), and increased specific gravity. Tubers from green foliage had higher specific gravities than those from desiccated foliage in two of five trials in this study.

The processing industry in the Columbia Basin prefers to use potatoes in the specific gravity range of 1.080 to 1.084 , with 1.084 being the optimum. Processing contracts give bonus values to Russet Burbank potatoes beginning at 1.077 and increasing to 1.084. Contracts for Ranger Russet do not have the bonus values due to the fact that specific gravities normally fit into the preferred range. Values for specific gravity of 1.075 and less are subject to crop rejection under terms of the contract. In the 1998 trials at Moses Lake where Russet Burbank was used, the nondefoliated plots had bonus values of $\$ 5.00$ and $\$ 2.00$ per ton on the east and west sides of the pivot, respec- 
tively, over the defoliated plots. At an average yield of 74 ton/ha, the bonus equated to $\$ 370 / \mathrm{ha}$ on the east and $\$ 148 /$ ha on the west sides of the pivot at Moses Lake. In 1999, where Ranger Russet was used at Bruce, tubers from the defoliated plots would have been rejected for processing with a potential loss of $\$ 2,966 /$ ha; whereas specific gravity for tubers from the nondefoliated foliage was in the acceptable range. Specific gravity of tubers at Cunningham in 2000 from the nondefoliated plots was closer to the optimum than those from the defoliated plots.

In this study, a higher incidence of late blight tuber rot occurred within $30 \mathrm{~m}$ of the center of the pivot. Tuber infection is favored near the center of the pivot where more irrigation water is delivered, because irrigation water washes sporangia from foliage onto soil (25), and survival of sporangia and zoospores of $P$. infestans is facilitated by a high water volume in soil (18). At every location, a significant reduction in percentage of rotten tubers was found with increasing distance from the pivot and with decreasing amounts of water. The different regression models showed a different rate in reduction of percentage of blighted tubers at each location, which could be due to different watering systems. The regression of the percentage of blighted tubers with distance from the pivot was best described by logarithmic and power curve models, and of the percentage of rotten tubers with the amount of irrigation water was best described by a linear model.

Infected tubers were not encountered at Cunningham in 2000, even though foliage was infected with $P$. infestans, probably because a water gradient across the plots was not present and plots received less water than the other locations. A high incidence of late blight tuber rot would not be expected at this location because relatively little tuber rot was found more than $30 \mathrm{~m}$ from the pivot in the other four field trials the previous 2 years.

The incidence and severity of late blight on foliage at vine killing was not related to incidence of tuber rot caused by $P$. infestans in this study. Similar results were observed in a previous study (6). A significant disease gradient on foliage over distance, which was not observed in this study, would be useful to investigate such a relationship. Late blight intensity on foliage over the course of the tuber-bulking period, cracking of the soil surface, and conditions favorable to washing of the spores from foliage to soil may be related to incidence of tuber infection. Various factors influence late blight tuber rot, and additional field research is needed to quantify the influence of late blight severity on foliage with the incidence of tuber rot.

Late blight is often more severe on potato foliage near the pivot center where additional irrigation water is often applied. Final late blight severity and incidence on foliage were not related to amount of water applied in this study. Late blight severities and incidences on foliage over time, duration of wet periods on foliage, and time of day of wet periods would additionally be needed to adequately investigate the relationship.
Discrete sections in potato storages containing rotten tubers are often encountered and can result in the loss of the entire storage. Such sections often house the potatoes harvested from specific areas of fields where the tubers were infected with $P$. infestans (unpublished data). Low areas of

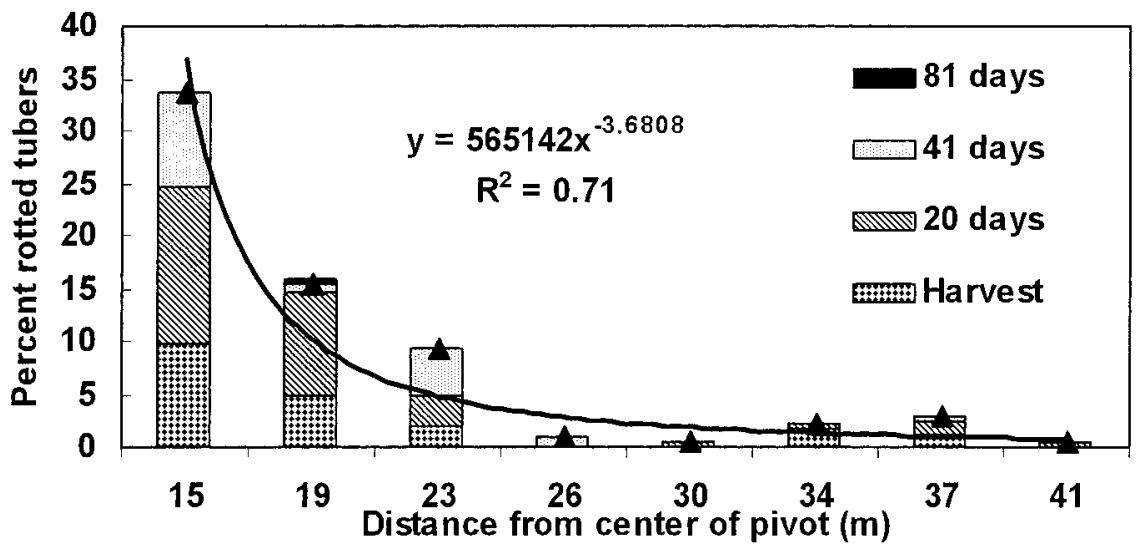

Fig. 4. Incidence of tubers of cultivar Russet Burbank infected with Phytophthora infestans in relation to distance from the center of an irrigation pivot system on the west side of a field near Moses Lake, WA, in 1998. Tubers were stored at $9^{\circ} \mathrm{C}$ and then assessed for rot over 20 weeks.

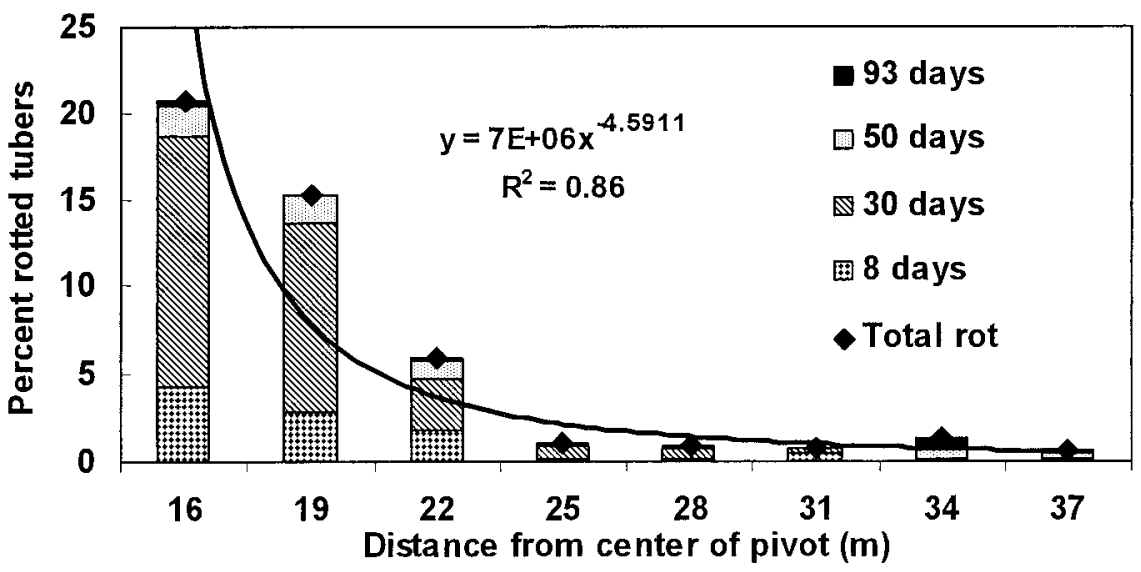

Fig. 5. Incidence of tubers of cultivar Ranger Russet infected with Phytophthora infestans in relation to distance from the center of an irrigation pivot system in a field near Bruce, WA, in 1999. Tubers were stored at $9^{\circ} \mathrm{C}$ and then assessed for rot over 20 weeks.

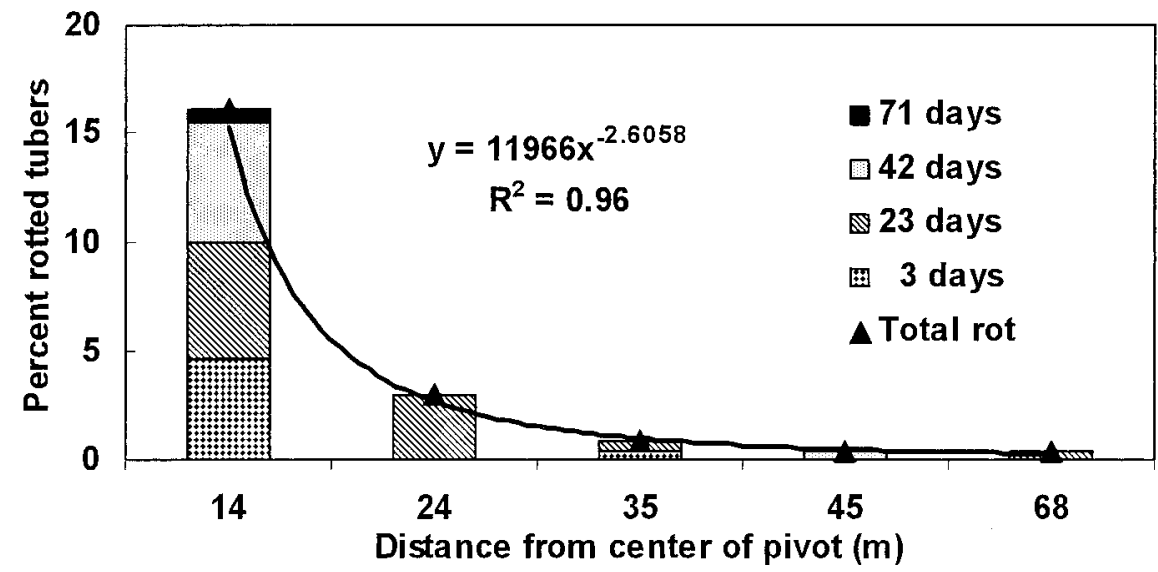

Fig. 6. Incidence of tubers of cultivar Ranger Russet infected with Phytophthora infestans in relation to distance of the center of an irrigation pivot system in a field near Cunningham, WA, in 1999. Tubers were stored at $9^{\circ} \mathrm{C}$ and then assessed for rot over 20 weeks. 


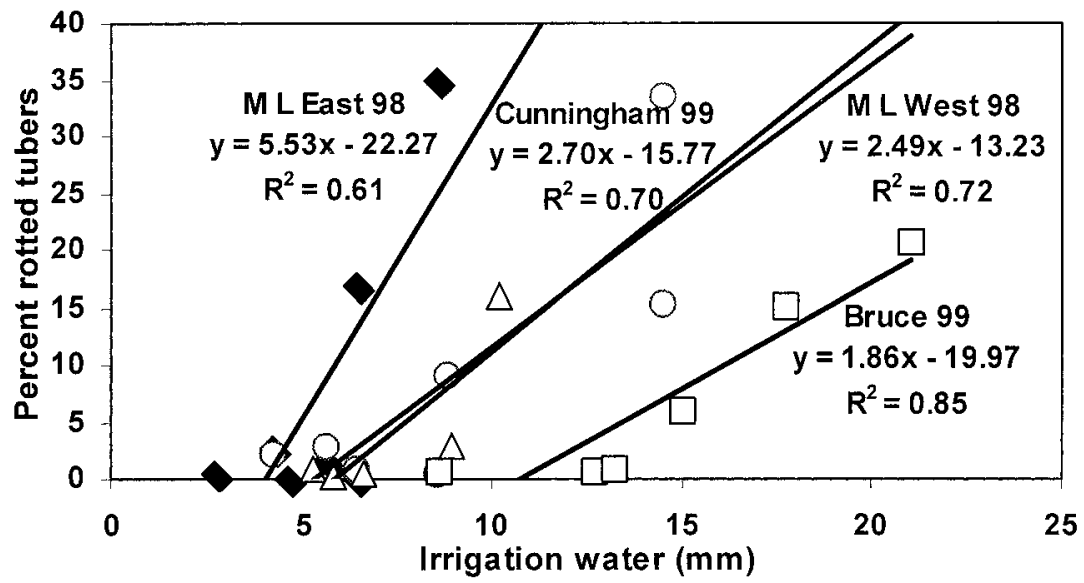

Fig. 7. Incidence of tubers infected with Phytophthora infestans in relation to amount of irrigation water applied in three potato fields in south-central Washington.

fields with poor water drainage and the area near the pivot, as found in this work, can have a high proportion of blighted tubers. When $P$. infestans is present, tubers from these areas should not be placed in long-term storage, or they should be placed in areas of the storage where they can be quickly removed. In this study, not growing potatoes within $30 \mathrm{~m}$ of the pivot would have reduced the total number of infected tubers going into storage, but this distance may vary depending on the water pattern of the specific irrigation system.

Tuber rot due to $P$. infestans was evident within 8 days of harvest, and the majority of infected tubers developed visible symptoms within 30 days of storage at $9^{\circ} \mathrm{C}$. This information is important for managing potato tubers and late blight in storage. Tubers that are infected or potentially infected need to be intensively monitored the first 30 days in storage. In addition, a tuber crop intended for overseas shipment to a country with a late blight quarantine can be assessed for late blight about 30 days after harvest with an expectation that tuber symptoms will be evident in infected tubers. Infected tubers held at $<5^{\circ} \mathrm{C}$ may not show obvious symptoms (19). Seed tubers are commonly stored at 3 to $4^{\circ} \mathrm{C}$.

Two recommendations for late blight management in the Columbia Basin can be derived from this research study. First, tubers intended for long-term storage should not be grown within $30 \mathrm{~m}$ of the pivot. This area of the field is difficult to irrigate without applying excess water. Modifying the water delivery pattern for a center-pivot system is not an option at this time because of engineering difficulties. The incidence of late blight infected tubers can be high from this relatively small area (about $0.15 \%$ of a typically sized 51-ha field), which poses a threat to noninfected tubers in storage. Tuber yields and tuber quality may also be reduced in this area of the field because of early death of plants from application of excess irrigation water. Many growers are currently applying this recommendation. Second, desiccation of potato foliage is not necessary for the management of late blight tuber rot when the crop has not been excessively irrigated (more water applied than lost through evapotranspiration), when timely fungicide applications have continued until harvest, and when harvest is done during dry weather. Additionally, experience in the field by Columbia Basin Processors has shown that tuber pulp temperatures need to be above $10^{\circ} \mathrm{C}\left(50^{\circ} \mathrm{F}\right)$ at harvest for successful storage of tubers harvested from green foliage. Tubers harvested from green foliage with pulp temperatures below $10^{\circ} \mathrm{C}$ have not stored well because of reduced wound healing and lower respiration rates (11).

\section{ACKNOWLEDGMENTS}

This research was supported by grants from the Washington State Potato Commission. We thank Maegan Davis for technical assistance, and D. A. Inglis, P. B. Hamm, and R. E. Thornton for their critical reading of the manuscript. PPNS No. 0332, Department of Plant Pathology, College of Agriculture and Home Economics Research Center, Chris Project 0678, Washington State University, Pullman 99164-6430.

\section{LITERATURE CITED}

1. Bonde, R., and Schultz, E. S. 1945. The control of potato late blight tuber rot. Am. Potato J. 22:163-167.

2. Goodwin, S. B., Schneider, R. E., and Fry, W. E. 1995. Use of cellulose-acetate electrophoresis for rapid identification of allozyme genotypes of Phytophthora infestans. Plant Dis. 79:1181-1185.

3. Inglis, D. A., Johnson, D. A., Legard, D. E., Fry, W. E., and Hamm, P. B. 1996. Relative resistances of potato clones in response to new and old populations of Phytophthora infestans. Plant Dis. 80:575-578.

4. Inglis, D. A., Powelson, M. L., and Dorrance, A. E. 1999. Effect of registered potato seed piece fungicides on tuber-borne Phytophthora infestans. Plant Dis. 83:229-234.

5. James, W. C. 1971. An illustrated series of assessment keys for plant diseases, their preparation and usage. Can. Plant Dis. Surv. 52:39-65.

6. James, W. C., Shih, C. S., Hodgson, W. A., and Callbeck, L. C. 1972. The quantitative relationship between late blight of potato and loss in tuber yield. Phytopathology 62:92-96.

7. Johnson, D. A., Alldredge, J. R., and Hamm, P. B. 1998. Expansion of potato late blight fore- casting models for the Columbia Basin of Washington and Oregon. Plant Dis. 82:642-645.

8. Johnson, D. A., Alldredge, J. R., and Vakoch, D. L. 1996. Potato late blight forecasting models for the semiarid environment of south-central Washington. Phytopathology 86:480-484.

9. Johnson, D. A., Cummings, T. F., and Hamm, P. B. 2000. Cost of fungicides used to manage potato late blight in the Columbia Basin: 1996 to 1998. Plant Dis. 84:399-402.

10. Johnson, D. A., Cummings, T. F., Hamm, P. B., Rowe, R. C., Miller, J. S., Thornton, R. E., Pelter, G. Q., and Sorensen, E. J. 1997. Potato late blight in the Columbia Basin: An economic analysis of the 1995 epidemic. Plant Dis. 81:103-106.

11. Knowles, L., Knowles, R., and Martin, M. 2001. Post harvest behavior of vinedesiccated vs. green-harvested Ranger Russet tubers. Potato Progress. Vol. 1, No 7. Washington State Potato Commission.

12. Kuehl, R. O. Design of Experiments - Statistical Principles of Research Design and Analysis. 2nd ed., Section 6.7, 2000. Duxbury, New York.

13. Little, T. M., and Hills, F. J. 1978. Agricultural Experimentation - Design and Analysis. John Wiley \& Sons, New York.

14. Miller, J. S., Cummings, T. F., Mikitzel, L. J., and Johnson, D. A. 2002. Influence of timing of harvest in relation to haulm killing and planting date on potato tuber rot caused by Phytophthora infestans. Plant Dis. 86:264-268.

15. Miller, J. S., Hamm, P. B., and Johnson, D. A. 1997. Characterization of the Phytophthora infestans population in the Columbia Basin of Oregon and Washington from 1992 to 1995. Phytopathology 87:656-660.

16. Miller, J. S., and Johnson, D. A. 2000. Competitive fitness of Phytophthora infestans isolates under semiarid field conditions. Phytopathology 90:220-227.

17. Miller, J. S., Johnson, D. A., and Hamm, P. B. 1998. Aggressiveness of isolates of Phytophthora infestans from the Columbia Basin of Washington and Oregon. Phytopathology 88:190-197.

18. Porter, L. D., and Johnson, D. A. 2002. Survival of sporangia and zoospores of Phytophthora infestans in surface water. (Abstr.) Phytopathology 92:S66.

19. Porter, L. D., Johnson, D. A., and Cummings, T. F. 2001. Development of Phytophthora infestans in potato tubers of nine clones in storage. (Abstr.) Phytopathology 91:S188.

20. Powelson, M. L., and Inglis, D. A. 1999. Foliar fungicides as protective seed piece treatments for management of late blight of potatoes. Plant Dis. 83:265-268.

21. Public Agriculture Weather System (PAWS) Remote Weather Stations. Washington State University-Prosser, Prosser. Published online.

22. Ribeiro, O. K. 1978. A Source Book of the Genus Phytophthora. J. Cramer, Vaduz, Germany.

23. Rotem, J., Palti, J., and Rawitz, E. 1962. Effect of irrigation method and frequency on development of Phytophthora infestans on potatoes under arid conditions. Plant Dis. Rep. 46:145-149.

24. Steel, R. G. D., and Torrie, J. H. 1960. Principles and Procedures of Statistics. McGrawHill Book Co., New York.

25. Stevenson, W. R. 1993. Management of early blight and late blight. Pages 141-1487 in: Potato Health Management. R. C. Rowe, ed. American Phytopathological Society, St. Paul, MN.

26. Thornton, R. E. 1995. Vine desiccation - some considerations. Spud Topics. Vol. 41, No. 6. Washington State Potato Comm., Moses Lake.

27. Washington Agricultural Statistics Service. 2001. 2001 Washington Agricultural Statistics. Wash. State Dep. Agric., Olympia. 